\title{
Certified Copy
}

National Cancer Institute

\section{Source}

National Cancer Institute. Certified Copy. NCI Thesaurus. Code C142417.

Reproduction of a primary document, in any format, that has on it an endorsement or certificate that it is a true 'copy' of the primary document. 